\title{
Are We on the Verge of a Major Transformation of the Global Economy?
}

\author{
Jacques Sapir* \\ Higher School of Social Sciences and Centre for Industrial Models, Higher School of Social Sciences, \\ Paris, 75006 France \\ *e-mail:dk1403@rambler.ru
}

Received April 24, 2020; revised May 18, 2020; accepted June 1, 2020

\begin{abstract}
The article contains an analysis of the events of world economic history related to the processes of globalization. The principles and nature of the functioning of international institutions that determine the world order in recent decades are described. In the context of significant changes taking place in the world in recent years, the question is raised of changing the balance of power in the world economy and the possibility of transition to its "deglobalization" is assessed.
\end{abstract}

Keywords: globalization, deglobalization, new industrialization, institutions, institutional economics, wto, world politics, international relations, currency markets

DOI: $10.1134 / \mathrm{S} 1075700720060118$

Introduction. The world economy regularly experiences more or less significant fluctuations and crises. It also experiences deeper changes, which affects both the balance of power between the main economies and the very logic of globalization. While it is difficult, in most cases, to precisely date these changes, we can nonetheless identify trend breaks and the emergence of new trends. The conjunction of these movements can herald significant changes.

Today, these movements are tending to de-globalize or to reduce the significance of global governance of the economy, a trend announced in a 2010 book [1], itself referring to other authors [2]. Here it is therefore necessary to clarify the concepts. The processe called in French of "démondalisation" means a return to more political forms of governance, to the detriment of the idea, and perhaps the illusion, that purely economic norms and rules could replace politics. De-globalization means on the other hand the reduction of global economic and financial interactions. These phenomena overlap only imperfectly. We can thus think of a process of governance re-politisation perfectly compatible with a high level of globalization. However, we also note that economic and financial interactions have tended to stagnate in recent years. The crisis caused by the coronavirus epidemic in early 2020 could, from this point of view, accelerate this movement of relocation of activities [3].

The phenomenon of relocation of economic activities has been widely observed these last years [4]. It is also accompanied by a "de-westernization" of the world [5]. This is a third phenomenon strongly linked to the two otehrs. These various phenomena are not only economic; they all have a political dimension as well as a cultural dimension. However, this text will focus mainly on the economic dimensions of these movements.

\section{The Slow Shift in World Economy Balance of Power}

The "world" economy did not really become global until the 1980s and 1990s. In fact, what was called the economic "world" was reduced from the beginning of the 19th century and until the 1980s to the "western" economy and its peripheries. If we look at the Bretton Woods agreements, which were intended to be a bulwark against a possible return of the Great Depression of the 1930s [6], we see that they in reality only concern the western part of the world. The USSR, which was an observer at the Bretton Woods conference [7], will withdraw from the process of establishing the IMF and the World Bank with the onset of the Cold War [8]. China will emerge from it at the same time, with the victory of the CCP and the proclamation of the People's Republic. In fact, the 1946 United Nations Conference on Trade and Employment which led to the adoption, on March 24, 1948, of the Havana Charter, contained clauses drafted so that the USSR could participate in a system world and despite the fact that its foreign trade was entirely under State control [9]. Despite this, the USSR refused to accede to the GATT, which had replaced the Havana Charter not ratified by the United States, even if, by the end of the 


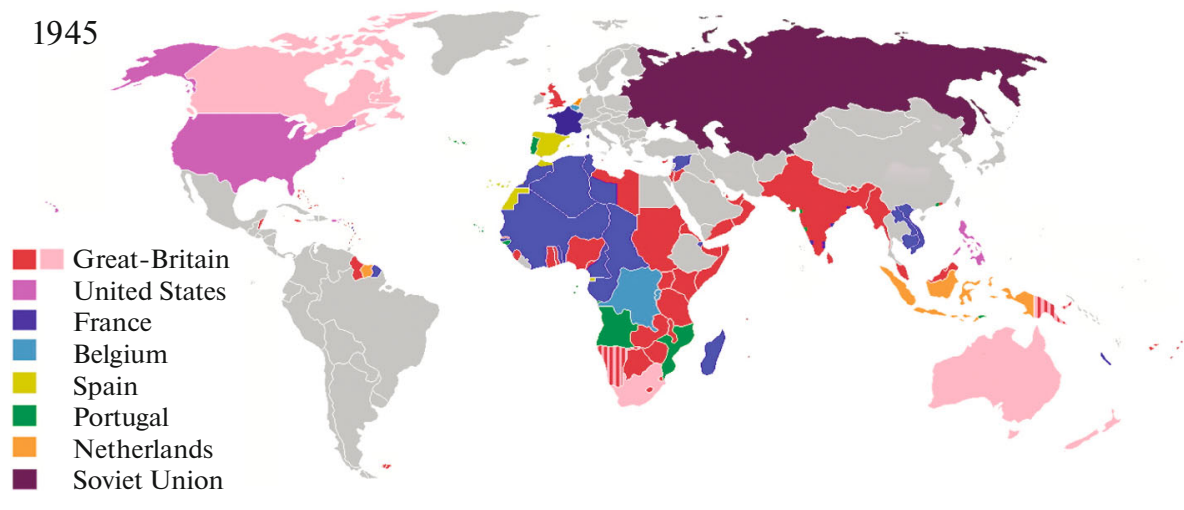

Fig. 1. Colonial empires and main countries in 1945.

1950s, it had revised its opinion on the major international treaties [10].

Much of Africa and Asia still lived under colonial rule in 1945 (Fig. 1). As for Latin America, it was only marginally affected by these agreements. The "international monetary system" then was only international by the name [11], as did the international trading system. The world economy will only "globalize" gradually, in a process that will be as much political as economic and monetary.

The march to globalization of the world. The Bretton Woods accords mark the willingness of the "grand alliance" countries to establish rules ensuring the stability of their trade after the victory [12]. However, these agreements were only concerning a limited number of countries; moreover, they were largely put on hold in the 1950s due to the shortage of foreign currency in Europe. The system that was then put in place to allow the development of international trade, the European Payments Union (EPU) was in reality contradictory to these agreements [13], and will not be dissolved until 1957 [14]. Indeed, the UEP is a limited convertibility system, which organizes clearing between member countries and leaves only annual balances to be paid in foreign currency. Japan will not be admitted until late under these agreements. The institutions created by the Bretton Woods agreements have a limited scope, be it the International Monetary Fund or the World Bank.

Two major changes will occur in the 1950s and early 1970s. The first was, unquestionably, decolonization, which brought new countries into the world arena [15] (see Fig. 1) but which also meant more subtly than formally independent countries (Egypt, Iraq, Iran) but in reality under the domination of a European power, regained all of their sovereignty.

The second change was the destruction of the bond between the Dollar and Gold. The Bretton Woods Agreements established two international reserve currencies, the Dollar and the British Pound, and fixed their Gold equivalent. The exchange rates of the other currencies were fixed, but adjustable. In December 1971, the United States suspended the convertibilityGold of the Dollar. In January 1976, the Jamaica Agreements officially confirmed the abandonment of the international legal role of gold and the general fluctuation of currencies [16]. There is therefore no longer an international monetary system which is "institutionally" organized even if a "dollar standard" develops which will generalize rapidly.

We could then speak of a form of "Bretton Woods II" [17]. It is true that this system, resulting from the unilateral rupture by the United States of the initial framework, was able to survive more than thirty years, from the mid-1970s to the mid-2000s. But, this system was and is actually very different from that of "de Bretton Woods" which lasted only from 1944 to 1971? This new system results above all in an international monetary "non-order", as the economist Jörg Bibow notes [18]. In the 1990s and 2000s there followed a series of major financial crises, which led many countries to seek to accumulate considerable foreign exchange reserves [19], an expensive task from which they could have been freed if the international monetary system had been truly functional [20]. Fear of financial crises inducing sudden reversals in external trade balances is one of the main drivers of the constitution of these foreign exchange reserves [21]. But, this system, as dysfunctional as it is, makes it possible to maintain the hegemony of the United States, a hegemony, which, until the 2000s, was not be disputed.

President Richard Nixon's decision of 1971 will therefore open a period of thirty years of economic hegemony for the United States. Countries like Japan and Germany will nonetheless challenge this hegemony, indirectly. However, the geostrategic power of the United States allowed them to muzzle this challenge. This period will also be marked by the shift from GATT to the WTO, and the temporary triumph of the ideology of free trade. However, this period will see changes unfolding, slow for some, dramatic for others, which will begin to undermine this hegemony. 


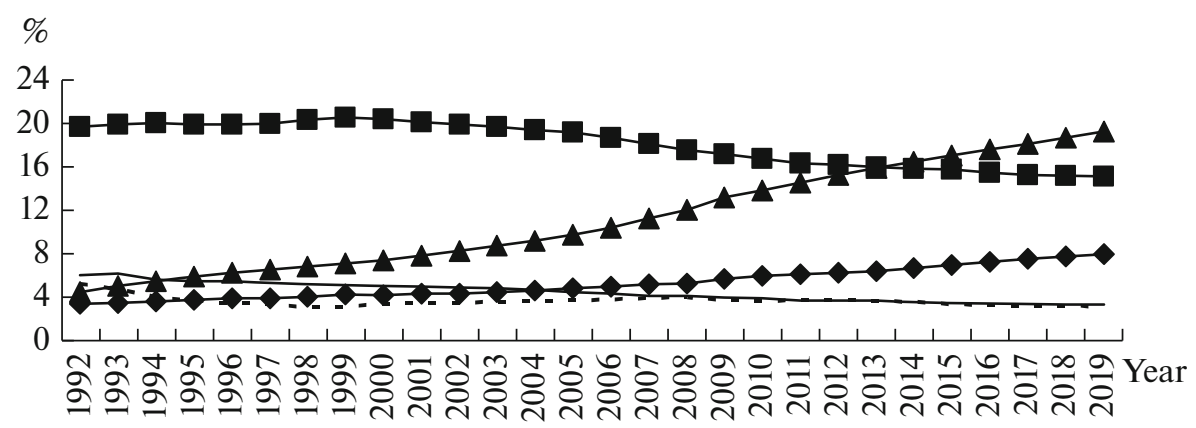

Fig. 2. Share of world GDP (in PPP). - - United States; $\neg-$ China; - - India: - - - Russia; — Germfny. Source: IMF, World Economic Outlook database.

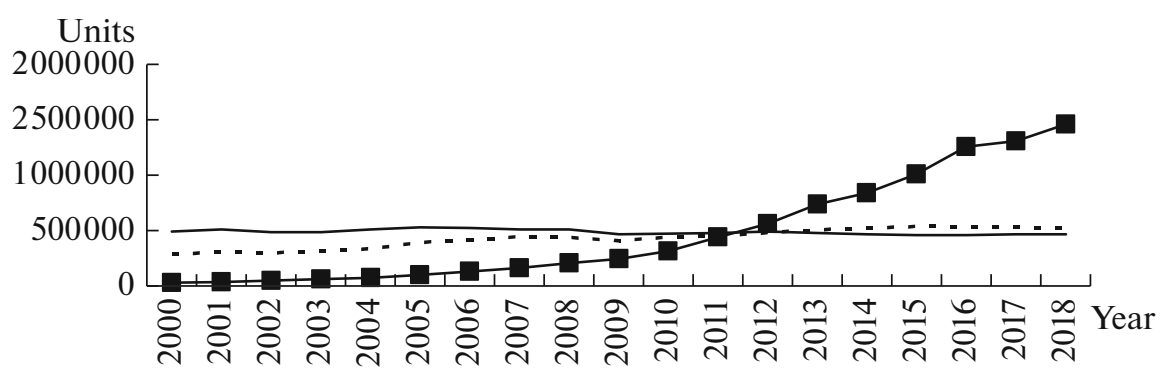

Fig. 3. Number of world patents. - - - United States; — Japan; - — China. Source: https://www3.wipo.int/ipstats/IpsStatsResultvalue.

- China's reintegration into the world economy (late 1980s) and the rapid Chinese growth that will ensue. bloc".

- The break-up of the USSR and the "Soviet

- The "emergence" process on the part of economies that were previously considered "developing" or even "underdeveloped".

In fact, the economic balance of power will be gradually modified. The birth of a truly "global" economy has also had the effect of "de-westernizing" the world.

The change of power relationships. This change in the balance of power was therefore made more obvious by what has been called the "emergence process". At the outset, these words were just describing the emergence of financial markets. These countries were the so-called "emerging markets". So the anagram "BRIC" originally came from a Goldman-Sachs report [22]. But, this formula will gradually be diverted to describe something much less financial. Thus, gradually, by "emergence" we meant to take into account the phenomenon of industrialization or re-industrialization, which affected many countries. This process resulted in an increase in their share in world GDP.
It can be seen in Fig. 2 that the share of world GDP achieved by the United States has started to fall sharply since 2000. The economy of the United States has been progressively overtaken, at least in purchasing power parity (PPP), by the one of China since 2013.

Less spectacular, but just as significant, was the rise in power of the Indian economy which progressed slowly from 1992 to 2002 (3.6\% to $4.4 \%)$, but much faster afterwards, since it reached, in 2019, around $8 \%$ of world GDP. The rise of India is also a very significant change in the global balance of power. Conversely, we see that Germany's share in world GDP is decreasing, even if its trade surplus is increasing and has exceeded China's one for years.

Of course, GDP is just one indicator among many.

In terms of the number of patents registered, we nevertheless note that here too China has done more than to catch up with the United States and Japan (Fig. 3). The overtaking of the United States by China, which dates back to 2011, is therefore a phenomenon which, on a historical scale, is comparable only to the overtaking of Great Britain by the United States at the beginning of the Twentieth century. It corresponds to a rise in Asia, to the detriment of North America and Europe (Fig. 4). 


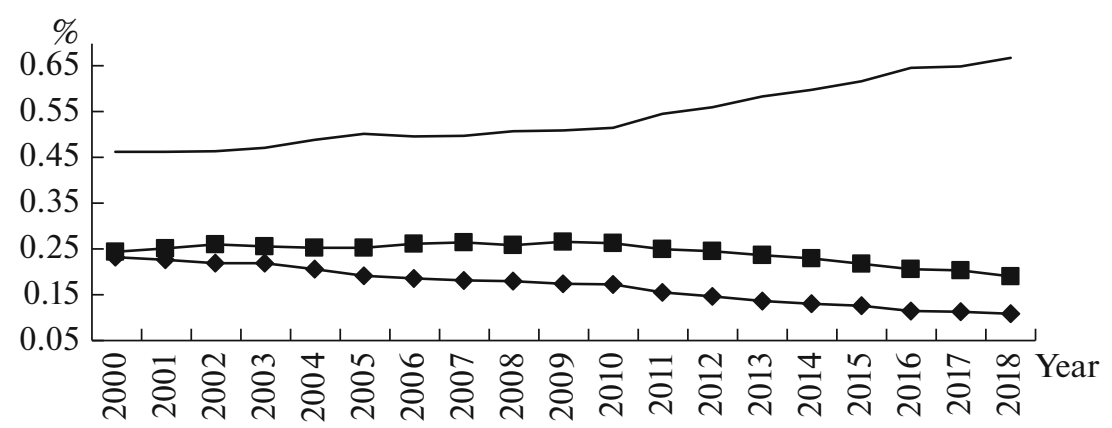

Fig. 4. Geographical zone percentage in world patents. - - Northern America; — Asia; —— Europe. Source: same as in Fig. 3.

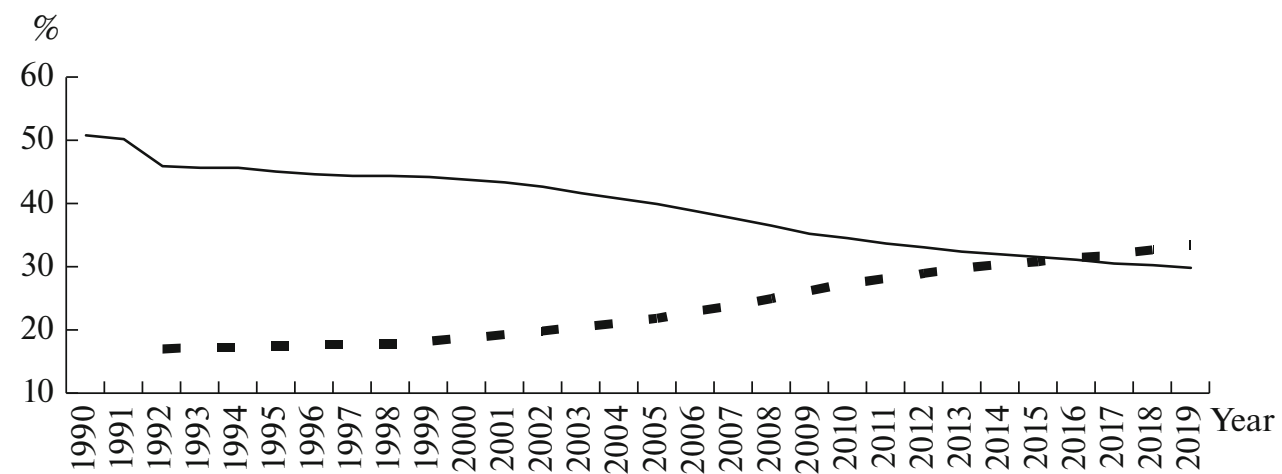

Fig. 5. Respective shares of G7 and BRICS in world GDP (in PPP) G-7; - - - BRICS. Source: same as in Fig. 2.

This rise in Asia, first generated by the importance assumed by Japan, which developed its own research capacities from the 1970s on and then by the other countries of Asia, is today drivent in particular by China and Korea. This process can be compared in the intangible field of the knowledge economy to the equivalent of the theory of the "flight of wild geese" which had been theorized in 1937 by Kaname Akamatsu [23]. This theory has also been used to try to explain the rise of Asia in international trade [24]. Very clearly, what we are witnessing today is a process of "de-westernization" of the world economy.

The Power of alliances. The big countries only face each other very indirectly. They seek to minimize their disagreements, see their antagonisms, by means of alliances, which can be as formal as informal, as economic as political or even military. In fact, around the United States a group of countries was initially formed to manage monetary issues. This group, the G-5 which became the G-7, saw its agendas develop rapidly in the 1990s and the 2000s. It integrated, for a few years, Russia before the latter was expelled from it. the aftermath of the Ukrainian crisis and the annexation of Crimea to Russia. But in the 2000s and 2010s, another group of countries was formed, the so-called BRICs and then the BRICS.
When the BRICs group was formed, countries weigh composing it was making only $20 \%$ of world GDP, while the United States was roughly at the same level, and the group of G-7 countries was around $43 \%$ (Fig. 5). The BRIC weight increase was then spectacular. The BRIC group, to which the Republic of South Africa has joined, has also established joint institutions, such as a development bank. But one could argue it was only translating the rise of China. So, can the shift in the balance of power be attributed to the rise of the Chinese economy?

Naturally the latter played an important role. But, if we remove China from the BRICS and the United States from the G-7, we find the same dynamics. Of course, the movement is less spectacular. However, the fall of the G-7 without the United States is as impressive as that of the G-7 with the United States (Fig. 6).

That's why looking at the same graph without China in the BRICS nor United States in the G-7 is also interesting.

The countries of the "first wave" are countries where industrialization appeared as a driving form of production in the years 1780-1840. These countries are characterized by the dominance of the textile and steel industries, generally adopt free trade rules, and are also major financial powers [25]. 


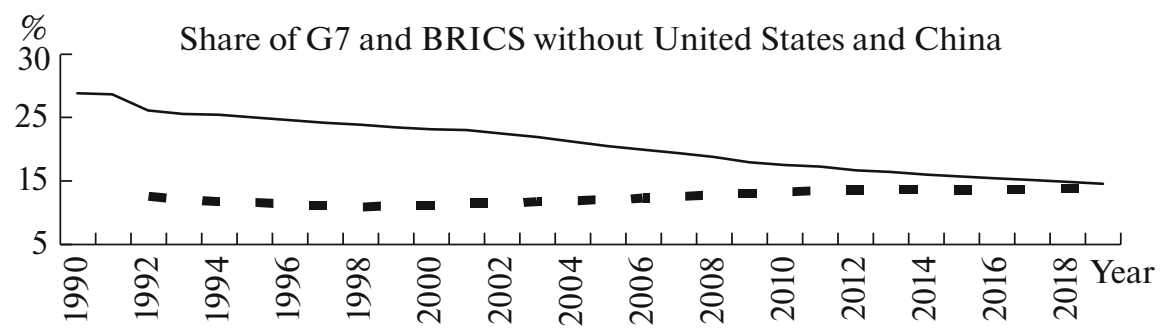

Fig. 6. Share of G7 and BRICS without United States and China. IMF, as in Fig. 2.

Second wave countries were rocked into industrialization from 1850 to 1910 , often under pressure or in reaction to "first wave" countries. They were the first "latecomers" countries in the Gerschenkron typology [26]. They were much more protectionnist (Russia [27], Japan, Germany, United States) but remained partly in financial dependence on the so-called "first wave" countries. Some of them even conserved some of their specific institutions [28]. Thus, the United States did not become dominant in the financial field until after the First World War. The case of Japan is special here because it has managed, by combining a policy of competitive emulation AND a very strong presence of the State, to relate to the third wave of emergence, in particular in the electronic field [29].

The "third wave" countries emerged in the 1950s and 1980s and were often former colonies (Korea, Taiwan, Malaysia, Singapore). These countries, too, can be characterized as "latecomers" [30]. They are characterized by the ideological domination of the "Japanese model" of industrialization with a very strong state, authoritarian political structures, at least in the initial phase, and benefit massively from the presence of the United States in Southeast Asia (and the Vietnam War) to develop. These countries, in particular Korea and Taiwan, will gradually develop their own innovation structures [31] and contribute then to the growth of Asia's share of patent filings.

The "fourth wave" countries were partly communist countries that have successfully transitioned, partly "imitating" countries of the "third wave" countries or are drawn by the development of China. They benefit from the offshoring movement initially, due to extremely low wage costs [32], but then develop in upstream supply chains. The weight of the state is also important [33]. In addition, two countries in this group, China and India, have developed quite a remarkable innovation capacity, one that is reflected by the swelling of the weight of Asia in patent applications.
We have been witnessing, for the past ten or fifteen years, a fundamental evolution, which has resulted in the weakening of the Western powers. These were, to a large extent, the countries of the first wave of the Industrial Revolution. The United States and Germany can, however, be viewed as straddling the first and second waves, and Japan, the only "non-western" member of the G-7, is clearly a second wave country. Within the BRICS, there is one country characteristic of this second wave, Russia, but the other countries, China, India, Brazil and South Africa or countries which belong more to the fourth wave.

The important point to note is that the rise of the BRICS is largely due to that of China and India, two so-called "fourth wave" countries. Russia has only maintained its position. Brazil, meanwhile, sees its share decreases. The BRICS group thus appears to be dominated by the logic of "fourth wave" countries that are also largely Asian countries. It thus contributes powerfully to the "de-westernization" of the world.

\section{The Reversal of Trade Flows and the Potential Disintegration}

The dominance of free trade from the 1990s and the emergence of new industrial powers had caused a noticeable surge in trade, and in their share in world GDP, itself growing rapidly.

This phenomenon was partly real but was also accompanied by a statistical artefact linked to the decomposition of integrated sets (such as the USSR or the CMEA). Today, due to the rise in inequalities in developed countries [34], inequalities which have

Table 1. A short story of industrialization successive waves

\begin{tabular}{l|l|l|l}
\hline \multicolumn{1}{c|}{ 1st Wave } & \multicolumn{1}{|c|}{ 2nd Wave } & \multicolumn{1}{c}{ 3rd Wave } & \multicolumn{1}{c}{ Wave } \\
\hline Great Britain & Germany & South Korea & China \\
France & Russia & Taiwan & Thailand \\
Belgium & Japan & Malaysia & India \\
Switzerland & Italy & Singapore & South Africa \\
& Czechoslovakia & & Brazil \\
& United States & & \\
\hline
\end{tabular}




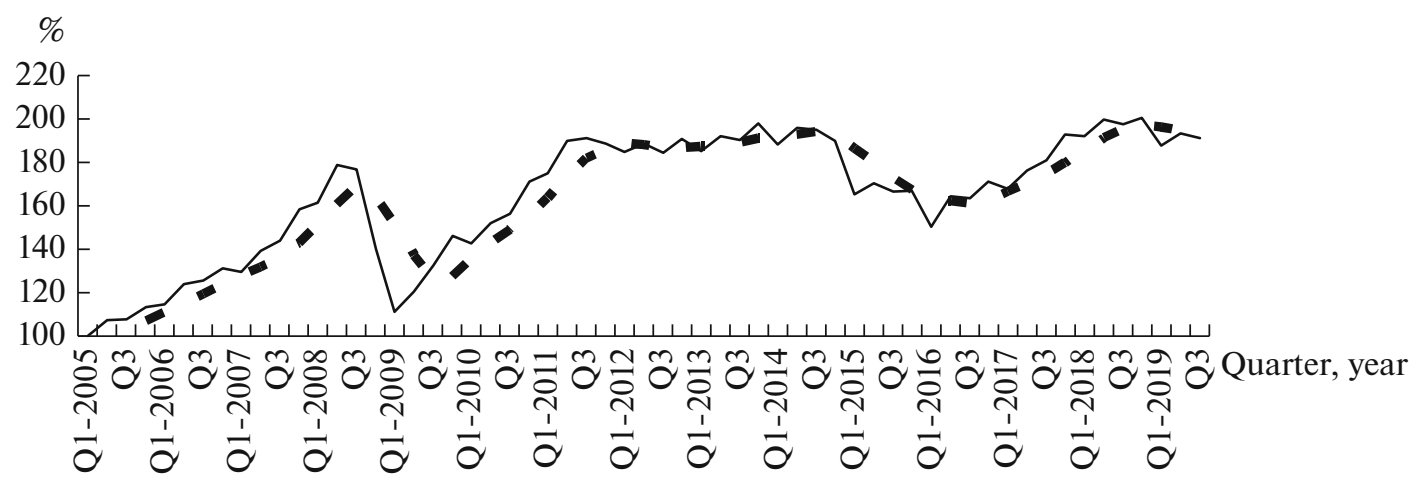

Fig. 7. Global qrade qrends. __ Clobal exports index; - - - Moving average on four quarters. Source: WTO.

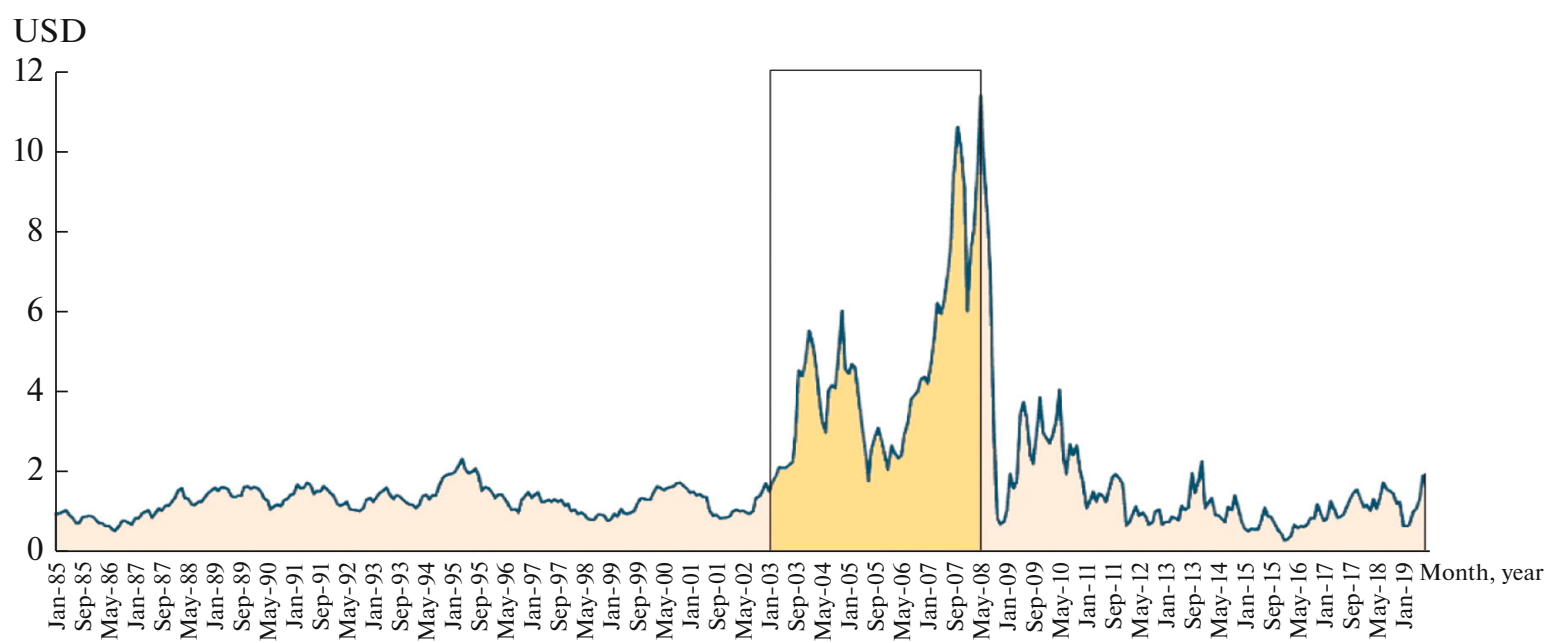

Fig. 8. Changes in the Baltic Dry index from 1985 to 2019. Source: https://transportgeography.org/?page_id=5619.

developed with the opening up to world trade [35], but also from a better appreciation of the evolution of real wage costs, it seems that this movement is reversed. This point is important because it shows the entry into a new international trade regime from which all the consequences have not yet been drawn.

The stagnation of trade in volume. The first striking point is the stagnation of world trade in volumes (Fig. 7).

The sum of world exports, which is also the sum of imports, is used as an indicator. A volume indicator is also used so that movements affecting relative prices do not distort the calculation. We can therefore see that, from 2005 to 2008 , we went from index 100 to index 180 in 13 quarters, an increase of $+20 \%$ per year approximately. From the second quarter of 2008 to the third quarter of 2019, the increase was much smaller, since we are at the index of 192. Of course, theses were the consequences of the financial crisis of 2008-2009. The "Baltic Dry" index shows it too (Fig. 8).

This index is an estimate of the average price for shipping raw materials (such as coal, iron ore, cement and grain) on a number of shipping routes and by size of ship. It is therefore an indicator of the cost paid for shipping raw materials to world markets and an important component of input costs. As such, the index is considered to be a leading (forward-looking) indicator of economic activity, as it involves events taking place in the early stages of the global commodity chains (sourcing and processing of raw materials). A high index indicates a limited maritime supply due to high demand and is likely to create inflationary pressures along the supply chain. A sudden and sudden drop in BDI is likely to predict a recession, as producers have reduced demand considerably, leaving shippers to cut prices significantly in an effort to attract freight.

We can clearly see in Fig. 8 the period of great tension in maritime transport which begins in January 2003 and which ends in May-June 2008, due to the crisis. The post-crisis period tends to show a "Baltic Dry" index at levels below the average levels observed from 1985 to 2002. The developments in this index for 


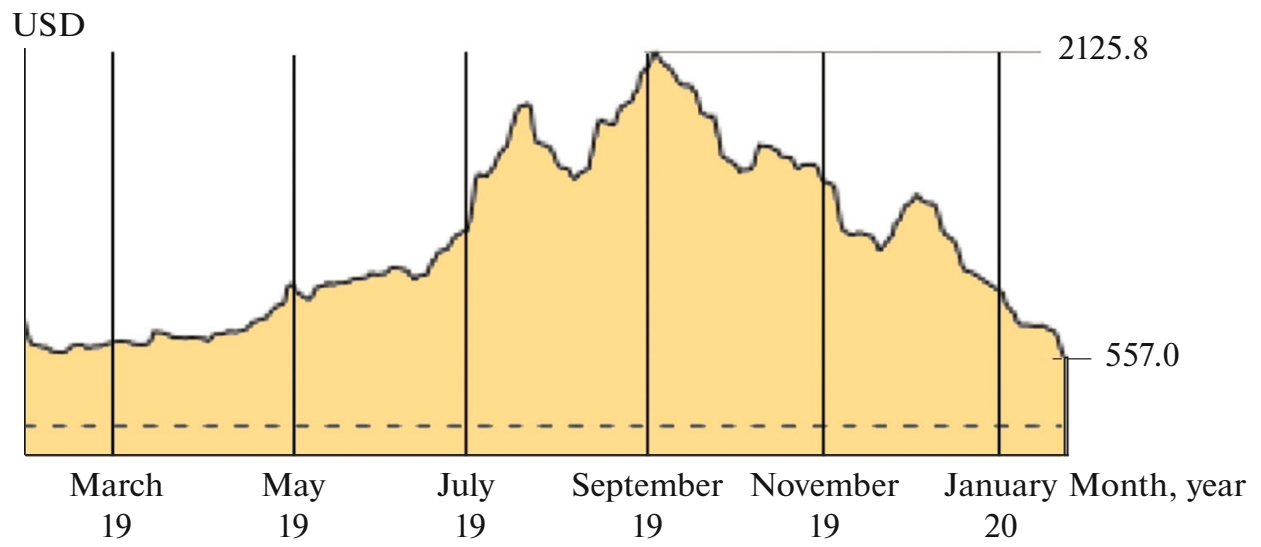

Fig. 9. Value of the "Baltic Dry” index from May 2019 to January 2020. Source: https://www.bloomberg.com/quote/BDIY:IND.

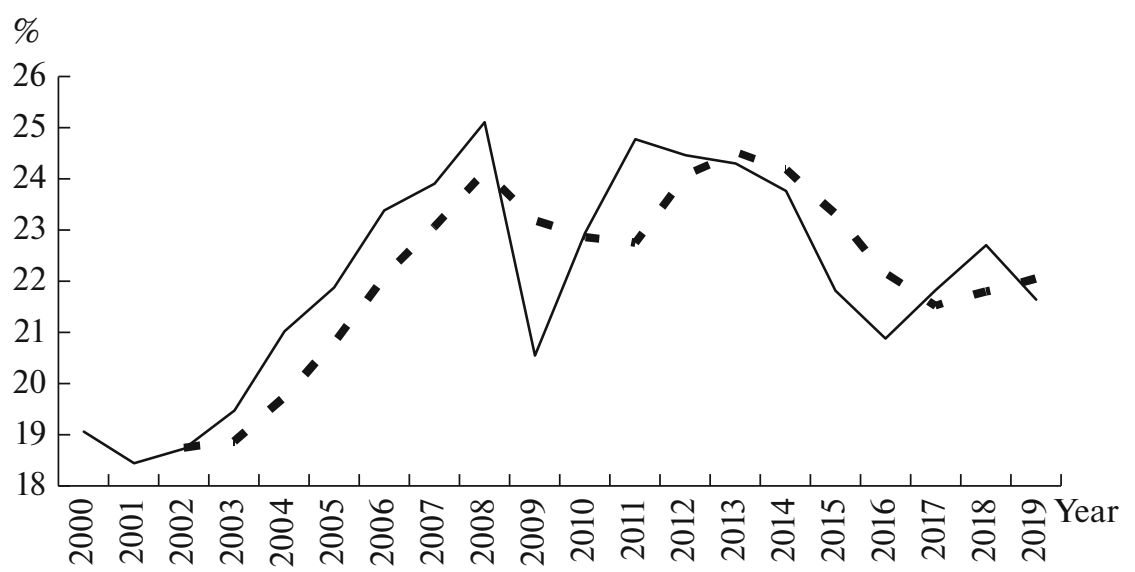

Fig. 10. Export of world GDP _ and trend on average for 3 years - - - in \% Source: IMF data base.

2019, as we can see in Fig. 9, confirm that we are witnessing a strong slowdown in world trade, since the value of this index fell below 600 at the end of January 2020.

The same is true if we look at the percentage share of international trade in world GDP. There was a sharp rise from 2002 to 2008, which was brutally broken by the financial crisis. After this crisis the weight of international trade in world GDP stagnates and then decreases from 2013.

The levels reached are important to keep in mind. The share of international trade in GDP was around $18.5 \%$ in 2001; it reached more than $25 \%$ in 2008. Since then, it has dropped to around $21.8 \%$ for 2019 (Fig. 10). This clearly indicates that the weight of international trade in world wealth is itself decreasing. On the other hand, this also tells us that an increasing share of wealth is produced to supply the internal markets of the various countries. The drop in exports worldwide is also a drop in imports. Large exporting countries, such as China, are refocusing on their own populations. Countries which have not understood this new logic and which remain faithful to the logic of growth driven by international trade, of production oriented for export suffer, as is the case of Germany today.

The importance of this turning point in 2012-2013 cannot be underestimated.

The illusion of free trade and the fragmentation of world trade. It therefore seems that the period 20002008 was "extraordinary" in more than one sense of the term. It was in 1995 that the WTO replaced the GATT and the 2002 meeting in Genoa was marked by violent incidents. You would think that free trade would quickly become the general rule. The WTO, however, was quickly struck with paralysis. The "Doha Round" turns out to have been a dead end [36]. Likewise, the sentiment born of these years, which led to trade being a cause of world growth and not a product of it, evaporated with the crisis of 2008-2009 and its consequences. This free trade has therefore also become an international sticking point [37], as we have seen since the election of Donald Trump in the United States [38]. 
In fact, the latter was content to radicalize a policy already started under Barak Obama [39].

Large exporting countries, such as China, are refocusing on their own populations. Countries which have not understood this new logic and which remain faithful to the logic of growth driven by international trade, of production oriented for export suffer, as is the case of Germany today. In other words, the quantitative impact of "globalization" has been declining for several years. This movement is also found when we look at the changes in the index of openness of the various groups of countries, an index calculated by relating to their GDP the amount of their international trade (imports and exports). After having increased from 2006 to 2011, it sometimes fell quite considerably from 2011 to 2016. It is therefore clear that the process of de-globalization does not correspond to a representation but rather to facts.

One can object here that what we are describing is only a transition phase between a globalization dominated by the United States and a new phase of globalization, which would be dominated by China. Doesn't the initiative launched by the latter, the huge "one belt, one road" project, recreate a multilateral framework [40], but under Chinese domination? However, when we look precisely at the content of this initiative, we see that it combines ambitious investment projects in transport [41], and cooperation frameworks that are all bilateral frameworks. These frameworks have both an economic and a commercial scope, and a geopolitical scope [42]. In fact, China seems more eager through this project to secure its supplies but also its markets than to develop an overall framework for the production of common standards.

The United States, for its part, has turned its back on multilateral agreements, which it has championed for decades. They have entered into comprehensive bilateral negotiations with China, recognizing in fact that the States, the States other than themselves, matter. The implementation of various measures, such as the Foreign Corrupt Practices Act and the Foreign Account Tax Compliance Act, was considerably aggravated by the decision of the American authorities to consider that any use of the Dollar automatically brought foreign companies under the law. American has then fostered the so-called principle of extraterritoriality. A parliamentary report on this problem was written in 2016 [43]. Through the policy of economic sanctions, which they use and abuse, and this is in reality well before the election of Donald Trump, and through their predatory policies towards non-American companies [44], they accelerate the fragmentation of the world economic space.

De-globalization then went from the stage of possibility, of virtuality, to that of fact; then it quickly went from that of fact to that of major fact. This is one of the lessons that we must learn from the often chaotic, sometimes contradictory developments that have manifested since 2010. The American withdrawal from the Vienna agreement with Iran (the Joint Comprehensive Plan of Action), did not exclusively aim to isolate Iran through economic sanctions. For fear of reprisals due to the extraterritorial application of American law, the denunciation of this agreement has made it possible to hinder the smooth running of the business that Iran had hitherto maintained with European companies and states, in particular France and Germany. Apart from Italy and Greece, which have negotiated directly with the United States bypassing Brussels, no other European state has so far been able to benefit from US exemptions on Iranian oil exports. This unilateral withdrawal has had serious economic repercussions for European and in particular French companies such as PSA, Renault, Total and Airbus [45].

Politics are therefore not absent, on the contrary. In this, this initiative, even if it takes forms from globalization, is indeed the product of de-globalization.

The origins of this process of demondialization are therefore multiple; what made this turning point obvious was the crisis from 2007 to 2009, which we nicknamed the "subprime crisis". Other phenomena have also had their role, such as the turning point in Chinese economic policy for example. The forms of demonstrations are diverse, and are not limited to economic statistics alone.

\section{Are We Going Towards Monetary Fragmentation?}

As has been said, the international monetary system, after the early 1970s and the dismantling of the Bretton Woods agreement had become a system largely based on the Dollar [46]. However, the period from 2010, the date of the original publication of this work, to 2019 was also marked by another important phenomenon: the concrete questioning of the domination of the United States Dollar.

It should be recalled here that one of the arguments, which had presided over the creation of the euro was that which explained that this new currency would have the power to compete with the United States Dollar as the basis of the international monetary system. Indeed, since the breakup of the BrettonWoods agreements in 1971 (Washington agreement) [47] and 1973 (generalized floating of currencies) the world has lived in a dollar standard system.

Could the euro be a global competitor to the dollar? The question that arose with the creation of the euro was therefore whether we could challenge the Dollar as an international currency. Many authors have thought that this would be the case [48]. Some even predicted this to happen quickly [49]. This question was indeed important insofar as what was called "globalization" presupposed a relatively homogeneous monetary and financial space at the world level, what one can call a "smooth" space [50]. The maritime 
Respective shares of USD and Euro in Central bank reserves

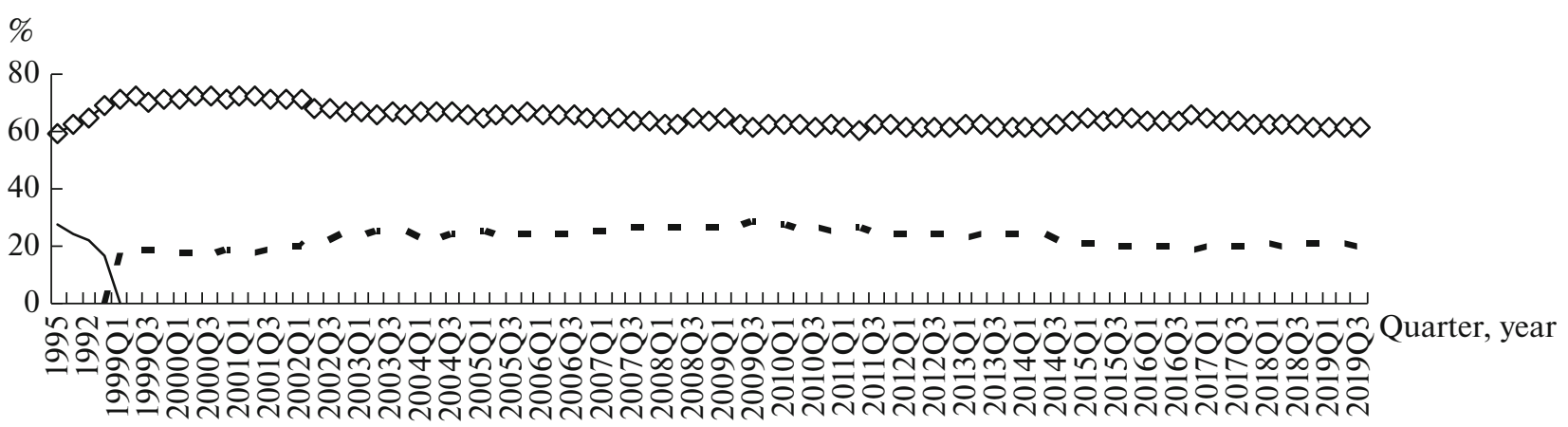

Fig. 11. Respective shares of USD and Euro in Central bank reserves. - $\diamond-$ USD share; - - - Euro share; — Share of $\mathrm{DM}+\mathrm{FF}+\mathrm{MthlG}+$ Ecu. Source: IMF, Composition of Foreign Exchange Reserves (COFER).

metaphor is tempting here. This space foreshadows the "liquid society" which is implicitly the model of total financialization [51]. In this "smooth" space, currencies can deploy freely, much like ships on the sea, or more precisely like shipping companies to which men and goods surrender for a transit. The challenge was therefore whether one or two currencies would be used in this space for transactions and investments.

So knowing whether the euro would assert itself as a competitor to the United States dollar was indeed an important issue [52]. Some hoped for a redefinition of global power relations [53] and a redefinition of the international monetary system [54]. This idea of a possible competition induced by the euro (and generally by the creation of the Economic and Monetary Union) was therefore very present in the course of the 1990s in the speeches which were held in Europe, but also in the United States [55]. It was clear to a number of writers that the creation of the euro would potentially upset the major international balances and give rise to a struggle for international seigniorage. This was implicitly the reasoning of Benjamin Cohen: “...international seigniorage, which can be analyzed as an implicit international transfer, is based on the will of non-residents to hold national currency or to use it outside the country of 'origin. The general circulation of a currency beyond its borders thus amounts to a subsidy or a loan without interests coming from the foreigners, which constitutes a real resource for the whole nation. However, international seigniorage can be exploited only as long as the national currency continues to be voluntarily held or that it circulates abroad" [56]. It should be noted, however, that this author quickly changed his position, developing a more moderate view of the ability of the euro to supplant the US dollar [57]. He wrote then, without this article dating from 2003: "My opinion, which risks disappointing many people, is deeply skeptical. The euro will obviously have a dominant position in internal European relations, and it will probably extend its influence to neighboring areas, such as the Mediterranean coast or sub-Saharan Africa - which the European Central Bank, the ECB (2001), calls the area of influence of the euro. (...). But everywhere else, for the foreseeable future, the new currency is destined to remain far behind the greenback, even if many Europeans would like it to be otherwise" $[57$, p. 8].

Yet, and contrary to what was argued both by this author and by Paul Krugman, the main issue was not the inertia that the dominant position of the dollar could have [57, p. 15. Krugman P.R. The international role of the dollar // in P.R. Krugman. Currencies and Crises. Cambridge, MA, MIT Press, ch. 10, 1992].

The international failure of the euro. In fact, the euro quickly occupied a relatively large place in the central banks' foreign exchange reserves. However, this position has in reality never exceeded that of all European currencies, Deutschemark, French Franc, Dutch Crown and ECU. This point is significant. This inability of the euro to exceed the sum of the main currencies of the EMU countries is proof that no specific dynamics for the euro have been unleashed, contrary to what a certain hope and sometimes feared some numbers of international experts. At its highest level, which occurred in the third quarter of 2009 when the financial crisis was in full swing, the euro is barely equal to what these four currencies represented in 1995 (Fig. 11). Since then, we have witnessed a slow but constant erosion of instead of the euro.

The share of the Dollar in the Central Banks reserves fell well from the beginning of 2002, seeming to accredit the hopes of some and the fears of others. However, the share of the Euro also fell from the middle of 2009. It has stabilized today around $20 \%$ of world foreign exchange reserves while the various European currencies represented around $27 \%$ of these same reserves. In other words, the euro is today significantly below the cumulative total of the currencies of the countries of the Euro zone in 1995. This is proof of the failure of the single currency in its project to 
Table 2. Foreign exchange turnover on the "Over The Counter" market Share of the top 5 currencies in bilateral foreign exchange transactions (in April of each year)*

\begin{tabular}{l|c|c|c|c|c|c|c|c}
\hline \multirow{2}{*}{ Currency } & \multicolumn{2}{|c|}{2004} & \multicolumn{2}{c|}{2013} & \multicolumn{2}{c|}{2016} & \multicolumn{2}{c}{2019} \\
\cline { 2 - 8 } & $\%$ & rank & $\%$ & rank & $\%$ & rank & $\%$ & rank \\
\hline Dollar & 88.0 & 1 & 87.0 & 1 & 87.6 & 1 & 88.3 & 1 \\
Euro & 37.4 & 2 & 33.4 & 2 & 31.4 & 2 & 32.3 & 2 \\
Yen & 20.8 & 3 & 20.3 & 3 & 21.6 & 3 & 16.8 & 3 \\
Pound & 16.5 & 4 & 11.8 & 4 & 12.8 & 4 & 12.8 & 4 \\
Australian Dollar & 6.0 & 5 & 8.6 & 5 & 6.9 & 5 & 6.8 & 5 \\
TOTAL & 168.7 & & 161.1 & & 160.3 & & 157.0 & \\
\hline
\end{tabular}

* The total is $200 \%$ because each transaction involves 2 currencies. Sources: BIS, Basel, 2019. https://www.bis.org/statistics/rpfx19.htm?m=6\%7C381\%7C677

challenge the dollar of the States-United. The initial ambition was, let us recall, that the euro largely exceeds the level of the total currencies composing it. We predicted such a movement because the euro was supposed to present many intrinsic qualities like its stability, its credibility but also its relative neutrality compared to the United States. So we see that it did not happen.

In fact, and according to statistics from the Bank for International Settlements, the dollar's share

The value of Table 2 is twofold. On the one hand, it shows the preeminent part of the American dollar, as we have said. It also shows that that of the euro, after having peaked in 2004, has regularly eroded this time, no longer as a reserve currency but as a transaction currency. But, on the other hand, it shows that the total share of transactions in the top 5 currencies continues to decrease in the total. Beyond the respective movements of the dollar and the euro, there has been

Table 3. Breakdown by currency of increases from the 2 nd quarter of 2016 to the 2nd quarter of 2019 (in millions of United States dollars)

\begin{tabular}{l|r|r}
\hline \multicolumn{1}{c|}{ Currency } & \multicolumn{1}{c|}{ Total } & $\%$ \\
\hline $\begin{array}{l}\text { Identified reserve cur- } \\
\text { rencies }\end{array}$ & 2459571.35 & \\
US Dollar & 1307076.33 & 53.1 \\
Euros & 566328.87 & 23.0 \\
Pound & 115018.55 & 4.7 \\
Yen & 115018.55 & 4.7 \\
Canadian Dollar & 43939.82 & 1.8 \\
Australian Dollar & 61037.48 & 2.5 \\
Swiss Franc & 2147.27 & 0.1 \\
Others & 16693.76 & 0.7 \\
Renminbi (Yuan) & 192968.48 & 7.8 \\
\hline
\end{tabular}

Source: FMI, Composition of Foreign Exchange Réserves (COFER). an increase in the share of "other currencies" in the reserves of central banks in recent years. Under this term, there is the Japanese Yen and the British Pound, but also the Canadian dollar and the Australian dollar, and finally, since 2016, the Renminbi (also called Yuan). Table 3.

The rise of "small currencies". These currencies have experienced some expansion as reserve currencies within central banks (Fig. 12). Over the 8 quarters which go from the 2 nd quarter of 2016 to the 2 nd quarter of 2018, a period which saw the Chinese currency accepted among the reserve currencies and which was marked by an increase of $23.4 \%$ in the overall amount of the reserves, the distribution of this total between these "new" currencies provides us with valuable insights.

The share of the United States Dollar continues to fall, that of the euro is recovering slightly, while remaining significantly lower than in 1995 the share of the aggregate of European currencies constituting the euro, and the Renminbi/Yuan makes a remarkable appearance with $7.8 \%$ of the total. Even more significant is the fact that all "other" currencies accounted for $22.2 \%$ of the reserves while the euro only represented $23 \%$. What this confirms to us is that we are also witnessing a trend towards fragmentation of reserve currencies. The period of "key currencies", like the sterling pound or the dollar, is coming to an end [58].

Of course, the United States dollar retains an important place, but on trend we see that this place is shrinking. Ultimately, it should only represent around $50 \%$ of reserves. This reduction in its role and this loss of its hegemony, if we remember that in the early $2000 \mathrm{~s}$ its share represented more than $70 \%$, is therefore not due to the euro.

The latter is unable to recover, or even exceed, the total shares in the reserves of the central banks of the individual currencies that compose it. It is indeed the emergence of the so-called "other" currency block that is today the engine of this change. 


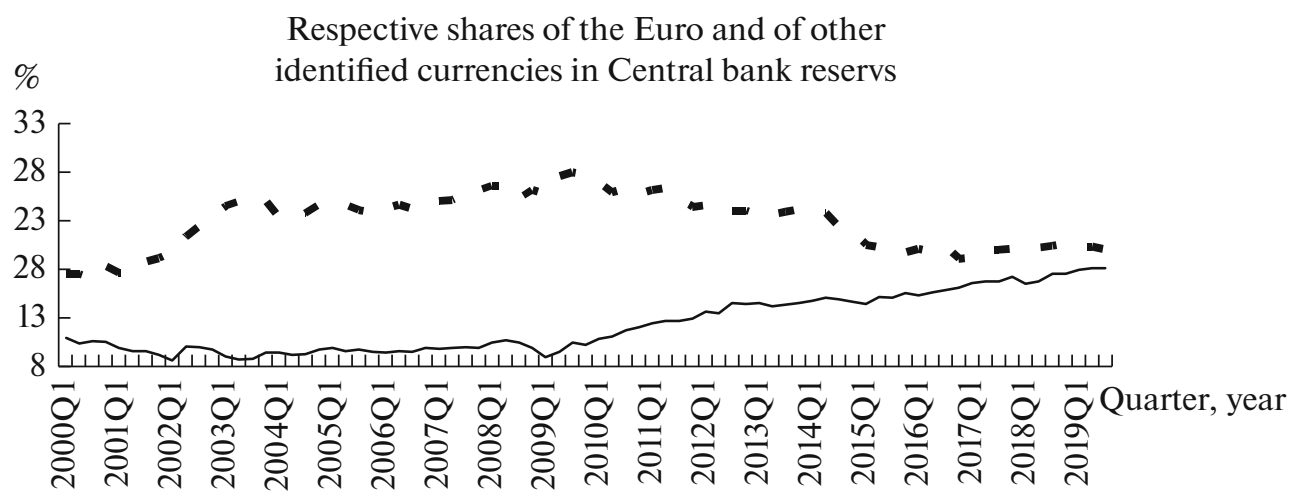

Fig. 12. Respective shares of the Euro and of other identified currencies in Central bank reservs. - - - Euro; —— Other identified currencies. Source: IMF.

What must then be understood is that this change is carried in part by currencies from the Asia-Pacific zone which achieve for 3 of them (Renminbi, Yen, Australian Dollar) almost $15 \%$ of the increase in currencies of reserves from the 2 nd quarter of 2016 to the 2nd quarter of 2019 (Table 3).

The trend is therefore towards fragmentation, and this fragmentation reflects both the uncertainties weighing on the use of the dollar, due to the sanctions policy of the United States, and the geopolitical fragmentation of the world, with the emergence new players with regional and global ambitions.

Ultimately, if the trend started continues, the Renminbi/Yuan could reach between 4 and $6 \%$ of the total, equivalent to the British Pound and the Yen. It could even exceed this level if the Chinese government decided to further liberalize the uses of the Yuan (or Renminbi).

As we can see, de-globalization, in the sense of the fragmentation of a space long considered to be smooth or "liquid", with the multiplication of vehicles, but also the specific nature of each person's rules, is a phenomenon that is developing even in the field international monetary.

\section{Towards the end of the "Global order"?}

A major change can therefore be noted between the current period and that of the 1990s and the beginning of the 2000s. The fall in the share of trade in world GDP, changes in the balance of power between economies, the phenomenon of monetary fragmentation in are all symptoms. We can speak of a trend towards demondialization.

This process, we must repeat, obviously does not make the exchanges disappear. It can even, under certain conditions, lead to their increase, but in another context. Even if, in some cases, the logic of the sub- contracting chains tends to renationalise, trade and financial exchanges will continue to be very important. However, these exchanges will be determined by national strategies, sometimes opposing each other, sometimes coordinated. And that, perhaps, is what best characterizes this movement of demondialization. The notion of "strategy", and in particular of "economic strategy" [59], is directly opposed to the notion of a globalized universe where everything would be governed by norms and rules. The importance of the concept of strategy is linked to that of radical uncertainty. The latter arises from the accumulation of complex influences on a given situation [60].

However, the rise in interactions linked to globalization has certainly led to the rise of these complex influences. Radical uncertainty generates surprise, which calls into question the cognitive rules with which individuals are endowed [61]. Therefore, the decision, in the form of a heuristic choice, has a better efficiency than the rule [62]. Here we see the importance of change: globalization has long been carried by an economic ideology which proclaimed that everything was reduced to probability [63] or that where uncertainty prevailed there could be no economy [64]. It is therefore globalization itself that has made this return to decision necessary, in other words to the political, as Carl Schmitt asserted a century ago [65], faced with a world that can no longer be managed by simple rules. This return to politics also implies the return of states.

Certainly, V. Kvint can affirm in a recent book that: «Strategy still remains surprisingly understimated, misused or misunderstood within certain powerful corporations, governments and military bodies» [66]. However, and it can be seen in the various fields which have been the subject of this study, it is the countries which have deliberately adopted strategies, such as China, India, Japan, Korea, but also in a to some extent Russia, who knew and were able to make the 
most of this globalization. It is therefore necessary to ask whether the process of globalization does not in itself generate the forces that push it to the contrary. The point that emerges is that what we can call "globalization", that is to say in reality an ideology which claims that the disappearance of politics and the triumph of impersonal rules and norms has lived. So we will never live in a "smooth" world [67].

This de-globalization certainly does not solve all the problems. Thus, the interdependence of the economies will continue, as will the major issues related to the development and management of natural resources. We also see it with the ecological question, which some improperly reduce to the question of climate change, but which is actually much deeper. We can also see this in the first quarter of 2010 with the coronavirus epidemic which, coming from China, will have important health and economic implications. However, the resulting problems will have to be resolved, or at the very least managed, with strict respect for each other's sovereignty. Here again, the coronavirus epidemic could prove to be a good metaphor for the world to come, because the different states preferred to take national measures than to wait for measures taken by supranational organizations. Let us add that this epidemic raises awareness in a particularly acute way of the question of pharmaceutical sovereignty in many countries [68].

This means that flows, both commercial and financial, will have to be put under control [69]. And we must tackle this question of control today, the principles which should govern this control, and not seek to return at all costs to "Free Trade" [70]. The rise of protectionism is obvious today, and it is not, far from it, a bad thing [71]. But, this protectionism must be thought, reflected. This is normally a work program which should be imposed on all political leaders. Here we find the key concept of strategy, and therefore of national priorities.

However, there is great resistance on this point in Europe. In fact, it is the leaders who advocate for full free trade who represent the women and men of the past today. Angela Merkel and Emmanuel Macron seem to have failed to understand the meaning of what happened from June 8 to 10, 2018 when the G-7 taking place in Canada in La Malbaie literally exploded [72] under pressure from Donald Trump [73]. They cling to old ideas. They defend indefensible treaties [74]. Because, the international context is cluttered with texts, which are for some obsolete, for others erroneous, and which sometimes combine these two aspects. From this point of view, the responsibility of Mrs. Angela Merkel is heavily engaged [75].

If we look at both the World Trade Organization and the G-7, it is rather the obsolescence of texts and institutions that strikes. Recall that the $\mathrm{G}-7$ originates from the G-5 (informal) and then from the G-6 from 1974-1975. At that time a part of the world (the communist countries) was not concerned and the grouping of countries represented by the G-6 (which became G-7 with the entry of Canada), which was mainly concerned with financial problems [76], actually represented the United States and its allies. The obsolescence of this institution is obvious. The same can be said of the WTO, which is now both paralyzed by internal blockages, and regularly circumvented both by new treaties and by states, as we saw with regard to sanctions against Russia in 2014. However, it is always dangerous to want to keep obsolete institutions. They maintain a fictitious framework while the reality of the situation has already evolved outside of this framework.

This tension over institutions, which are now outdated, while the phenomena of de-globalization and of politicising governance are now advancing rapidly, is in itself an important factor of crises.

\section{CONFLICT OF INTEREST}

The authors declare that they have no conflicts of interest.

\section{REFERENCES}

1. J. Sapir, La Démondialisation (Le Seuil, Paris, 2010).

2. W. Bello, Deglobalization, Ideas for a New World Economy (Zed Book, London-New York, 2002).

3. https://lexpansion.lexpress.fr/actualite-economique/ 1-economie-mondiale-survivra-t-elle-au-coronavirus_2117954.html.

4. A. Montebourg, foreword by d'Emmanuel Todd, Votez pour la démondialisation! Paris, Flammarion, 2011, or Pierre-Noël Giraud interview in Alternatives Economiques. https://www.alternatives-economiques.fr/pierre-noel-giraud-de-mondialisation-va-sens/00077277.

5. N. Barma, G. Chiozza, E. Ratner, and S. Weber, "A world without the West? Empirical patterns and theoretical implications," Chin. J. Int. Polit. 4 (2), 525-544 (2009).

6. B. Bernanke and H. James, The Gold Standard, Deflation, and Financial Crisis in the Great Depression: An International Comparison. Working Paper. No. 3488 (NBER, Cambridge. MA, 1991).

7. R. F. Mikesell, Negotiating at Bretton Woods. 1944, in Negotiating with the Russians, Ed. by R. Denett and J. Johnson (World Peace Foundation, Boston, 1951), pp. 112-116; R. F. Mikesell, "The Bretton Woods debates. A memoir,” Essays Int. Finance, No. 192 (1994).

8. V. E. Varga, "The Marshall Plan and the approaching economic crises in America," New Times, No. 39, 5-7 (1947).

9. M. L. Kostecki, “L'U.R.S.S. face au système de commerce multilateral," Rev. Etud. Compar. Est-Ouest 10 (3), 75-89 (1979). 
10. M. Kostecki, East-West Trade and the G.A.T.T. System (McMillan, London, 1979), Ch. 5.

11. A. Chalandon, Le Système Monétaire International (CES, Paris, 1966), A. Grjebine and T. Grjebine, "La réforme du système monétaire international," L'Économiste, No. 39 (1973).

12. A. Von Dormael, Bretton Woods: Birth of a Monetary System (Holmes Meir, London, 1978).

13. M. Jaoul and O. Schloesing, "l'Union Européenne des paiements," Rev. Econ. 5 (2), 263-277 (1954); E. James, "L'Union Européenne des paiements," Rev. Econ. 2 (5), 560-577 (1951); A. O. Hirschman, "The European Payments Union. Negotiations and the issues,” Rev. Econ. Stat., Fevrier 33 (1), 49-55 (1951).

14. H.-K. Von Mangoldt-Reiboldt, "De l'Union européenne de paiements à la convertibilité monétaire," Rev. Econ. 8 (1), P. 76-90 (1957).

15. B. Droz, Histoire de la Décolonisation au XXe Siècle (Le Seuil, Paris, 2009).

16. J. De Larosière, 50 Ans de Crises Financières (Odile Jacob, 2016).

17. M. Dooley, D. Folkerts-Landau, and P. Garber, An Essay on the Revived Bretton Woods System, Working Paper. No. 9971 (NBER, Cambridge, MA, 2003).

18. J. Bibow, "The international monetary (non-)order and the 'global capital flows paradox'," in Finance-led Capitalism?, Ed. by E. Hein, P. Spahn, T. Niechoj, and A. Truger (Metropolis, London, 2008).

19. J. Aizenman and N. Marion, "International reserve holdings with sovereign risk and costly tax collection," Econ. J. 114, 569-591 (2004); J. Aizenman and J. Lee, "International reserves: Precautionary versus mercantilist views, theory and evidence," NBER Work. Pap., No. 11366 (2005).

20. J. Aizenman and N. Marion, "International reserve holdings with sovereign risk and costly tax collection," Econ. J. 114, 569-591 (2004); J. Aizenman and J. Lee, "International reserves: Precautionary versus mercantilist views, theory and evidence," NBER Work. Pap., No. 11366 (2005).

21. B. Eichengreen and M. Adalt, "Current account reversals: Always a problem?," NBER Work. Pap., No. 11634 (2005).

22. J. O'Neill, "Building better global economic BRICs," Goldman Sachs, Global Econ., No. 66 (2001); D. Wilson and R. Purushothaman, "Dreaming with BRICs: The Path to 2050," Goldman Sachs, Glob. Econ., No. 99 (2003).

23. K. Akamatsu, "A historical pattern of economic growth in developing economies," Dev. Econ. 1 (1), 3-25 (1962); "Waga Kuni Yomo Kögyöhin no Bõeki Sūsei," J. Nagoya Higher Commer. Sch. (1935).

24. Y. Nobuharu, "Re-emergence of Asia and the rise and fall of the Japanese economy in super long waves of capitalist world systems," J. Contemp. Asia (2019). https://www.tandfonline.com/doi/abs/10.1080/00472336.2019.1651382.
25. P. Mathias, The First Industrial Nation. An Economic History of Great-Britain, 1700-1914 (Methuen, London, 1969).

26. A. Gerschenkron, Economic Backwardness in Historical Perspective: A Book of Essays (Belknap Press of Harvard University Press, Cambridge, MA, 1962).

27. T. H. Von Laue, Sergeï Witte and the Industrialization of Russia (Columbia University Press, New York, 1963); T. H. Von Laue, "The state and the economy," in The Transformation of the Russian Society since 1861, Ed. by C. E. Black (Harvard University Press, Cambridge, MA, 1960); K. C. Talheim, "Russia's economic development," in Russia Enters the Twentieth Century, Ed. by G. Katkov, E. Oberländer, N. Poppe, and G. von Rauch (Temple Smith, London, 1971).

28. J. Hirschmeier, "The origins of entrepreneurship," in Meiji Japan (Harvard University Press, Cambridge, MA, 1964); J. W. Bennet and I. Ishino, Paternalism in the Japanese Economy: Anthropological Studies of Oyabun-Kobun Patterns (University of Minnesota Press, Minneapolis, MN, 1963); G. Ranis, "The communitycentered entrepreneur in Japanese development," Explor. Entrepreneurial History 3 (2) (1955), M. Y. Yoshino, Japan's Managerial System-Tradition and Innovation (MIT Press, Cambridge, MA, 1968).

29. D. Okimoto, T. Sugano, and F. B. Weinstein, Competitive Edge: The Semiconductor Industry in the U.S. and Japan (Stanford University Press, Stanford, CA, 1984); D. Okimoto, Between MITI and the Market, Japanese Industrial Policy for High Technology (Stanford University Press, Stanford, CA, 1989).

30. M. Hobday, "East Asian latecomer firms: Learning the technology of electronics," World Dev. 23 (7), 11711193 (1995); J. A. Mathews, "Competitive advantages of the latecomer firm: A resource-based account of industrial catch-up strategies," Asia Pac. J. Manage. 19 (4), 467-488 (2002).

31. K. Lin-su, Imitation to Innovation: The Dynamics of Korea's Technological Learning (Harvard Business School Press, Cambridge, MA, 1997).

32. J. Sapir, La Démondialisation (Le Seuil, Paris, 2010).

33. V. R. Fernández and E. Ormaechea, "The state in the capitalist periphery: From the structuralist vacuum to the neo-structuralist deviations and beyond," in Development in Latin America, Ed. by V. Fernandez and G. Brondino (Palgrave Macmillan, Cham, 2019).

34. J. Bivens, Globalization, American Wages, and Inequality. Economic Policy Institute Working Paper (Washington, DC, 2007); G. Irvin, "Growing inequality in the neo-liberal heartland," Post-Autistic Econ. Rev., No. 43 (2007); R. Hira and A. Hira, Outsourcing America: What's Behind Our National Crisis and How We Can Reclaim American Jobs (AMACOM/American Management Association, 2005).

35. M. Förster and M. M. d'Ercole, "Income distribution and poverty in OECD countries in the second half of the 1990s," OECD Soc. Employ. Migr. Work. Pap., No. 22 (2006).

36. F. Ackerman, "The shrinking gains from trade: A critical assessment of Doha Round projections," Global 
Dev. Environ. Inst., Work. Pap., No. 15580 (2005); A. H. Charlton and J. E. Stiglitz, A Development-Friendly Prioritization of Doha Round Proposals. IPD Working Paper (Initiative for Policy Dialogue, New York-Oxford, 2004).

37. N. D. Graaff and B. V. Apeldoorn, "US-China relations and the liberal world order: Contending elites, colliding visions?," Int. Affairs 94 (1), 113-131 (2018).

38. J. Goldberg, "A senior White House official defines the Trump doctrine," Atlantic, June 11 (2018).

39. J. Sapir, "President Trump and free-trade," RealWorld Econ. Rev., No. 79, 64-73 (2017). http://www.paecon.net/PAEReview/issue79/Sapir79.pdf.

40. China Britain Business Council: One Belt One Road. http://www.cbbc.org/resources/one-belt-one-road/.

41. N. Liang, J. Tang, and J. Li, "La nouvelle route ferroviaire de la soie, pont entre la Chine et l'Europe," Echos de Chine, Jan. 18 (2017); J.-P. Rodrigue, The Northern East-West Freight Corridor (Eurasian Landbridge). http://www.people.hofstra.edu/geotrans/eng/ch5en/ conc5en/NEW_Corridor_Freight.html; The Geography of Transport Systems (Hofstra University, 19982009).

42. "La nouvelle Route de la Soie, une stratégie d'influence mondiale de la Chine," Epoch Times. http://www.epochtimes.fr/nouvelle-route-de-soiestrategie-dinfluence-mondiale-de-chine-28431.html.

43. https://www.assemblee-nationale.fr/14/rap-info/i4082.asp, R. Gauvain, C. D'Urso, A. Damais, and S. Jemai, Rétablir la Souveraineté de la France et de l'Europe et Protéger nos Entreprises des Lois et Mesures à Portée Extraterritoriale (Assemblee Nationale, Paris, 2019). https://www.vie-publique.fr/sites/default/files/ rapport/pdf/194000532.pdf.

44. "Alstom pleads guilty and agrees to pay $\$ 772$ million criminal penalty to resolve foreign bribery charges," US Department of Justice. Office of Public Affairs, Dec. 22 (2014). http://archive.wikiwix.com/cache/index2.php? url=https $\% 3 \mathrm{~A} \% 2 \mathrm{~F} \% 2 \mathrm{Fwww}$.justice.gov\%2Fopa $\% 2$ Fpr\%2 Falstom-pleads-guilty-and-agrees-pay-772-millioncriminal-penalty-resolve-foreign-bribery.

45. https://www.capital.fr/entreprises-marches/total-abandonne-south-pars-11-en-iran-a-moins-dune-derogation1288307.

46. J. Bibow, The Global Crisis and the Future of the Dollar: Toward Bretton Woods III? Working Paper No. 584 (Levy Econ. Inst., Annandale-On-Hudson, NY, 2010); J. Bibow, Bretton Woods 2 Is Dead, Long Live Bretton Woods 3? Working Paper No. 597 (Levy Econ. Inst., Annandale-On-Hudson, NY, 2010).

47. http://blogs.lesechos.fr/echos-d-hier/18-decembre1971-la-fin-de-bretton-a7951.html.

48. D. Gros and N. Thygesen, European Monetary Integration: From the European Monetary System to European Monetary Union, 2nd ed. (Longman, London, 1998); R. A. Mundell, "The euro and the stability of the international monetary system," in The Euro as a Stabilizer in the International Economic System, Ed. by R. A. Mundell and A. Cleese (Kluwer Academic. Boston, 2000), Ch. 5.
49. C. F. Bergsten, "The impact of the euro on exchange rates and international policy cooperation," in EMU and the International Monetary System, Ed. by P. R. Masson, T. H. Krueger, and B. G. Turtelboom (International Monetary Fund, Washington, DC, 1997), Ch. 2.

50. C. Schmitt, Terre et Mer (Pierre-Guillaume de Roux Editeur, Paris, 2017).

51. R. A. Berman, "Geography, warfare, and the critique of liberalism," in Carl Schmitt's. Land and Sea, présentation à la seconde édition anglaise de Terre et Mer (2015); R. A. Berman and S. G. Zeitlin, Land and Sea: A World Historical Meditation (Telos Press, Candor, NY, 2015).

52. B. J. Cohen, "L'euro contre le dollar: Un défi pour qui?," Polit. Étrangère 62 (4), 583-595 (1997).

53. D. Gros and N. Thygesen, European Monetary Integration (St. Martin's Press, New York, 1992).

54. A. Bénassy, A. Italianer, and J. Pisani-Ferry, "The external implications of the single currency," Econ. Stat., Special Issue, 9-22 (1994).

55. N. Thygesen et al., International Currency Competition and the Future Role of the Single European Currency. Final Report of a Working Group on "European Monetary Union-International Monetary System (Kluwer Law International, London, 1995).

56. B. J. Cohen, "L'euro contre le dollar: Un défi pour qui?,” Polit. Étrangère 62 (4), 583-595 (1997).

57. B. J. Cohen, "Pourquoi l'euro n'est pas près de remplacer le dollar," Econ. Polit., No. 20, 8-31 (2003).

58. M. Aglietta, “Ce fut d'ailleurs l'une des prémonitions de Michel Aglietta, même si dans les faits le processus est assez différent à ce qu'il avait imaginé," in La Fin des Devises Clés (La Découverte, Paris, 1986).

59. V. Kvint, Strategy for the Global Market (Routledge, New York, 2016).

60. J. M. Keynes, Treatise on Probability (Macmillan \& Co, London, 1921).

61. G. L. S. Shackle, Expectations in Economics (Cambridge University Press, Cambridge, 1949); G.L.S. Shackle, Imagination and the Nature of Choice (Edinburgh University Press, Edinbourg, 1979).

62. A. de Groot, Thought and Choice in Chess (La Haye, Mouton, 1965); H. A. Simon, "Theories of bounded rationality," in Decision and Organization, Ed. by C. B. Radner and R. Radner (North Holland, Amsterdam, 1972), pp. 161-176.

63. T. Haavelmo, "The probability approach to econometric,” Econometrica 12 (1944).

64. R. E. Lucas, Studies in Business Cycle Theory (MIT Press, Cambridge, MA, 1981); R. E. Lucas, "An equilibrium model of business cycle," J. Polit. Econ. 83, 1113-1124 (1975).

65. C. Schmitt, Théologie Politique (Gallimard, Paris, 1988), p. 16.

66. V. Kvint, Strategy for the Global Market (Routledge, New York, 2016), p. 3.

67. J. Sapir, La Démondialisation (Le Seuil, Paris, 2010). 
68. https://www.lecourrierdesstrateges.fr/2020/02/14/sile-coronavirus-menace-notre-approvisionnement-enmedicaments/; https://www.challenges.fr/entreprise/sante-et-pharmacie/coronavirus-face-au-spectre-d-une-penurie-de-medicaments-1-ue-alerte-leslabos-rassurent_698818.

69. Y. Perez, Les Vertus du Protectionnisme-Crises et Mondialisation, les Surprenantes Leçons du Passé (L’Artilleur, Paris, 2019).

70. J. Sapir, "Le protectionnisme et la fureur de ses ennemis," in Le Protectionnisme et Ses Ennemis (Éditions Les Liens qui Libèrent, Paris, 2012).

71. J. Sapir, "Crisis of globalization: The new context and challenges for national economies," in Contemporary Global Challenges and National Interest-The 15th International Likatchov Scientific Conference (St. Petersburg, 2015), pp. 142-145.
72. N. D. Graaff and B. V. Apeldoorn, "US-China relations and the liberal world order: Contending elites, colliding visions?,” Int. Affairs 94 (1), 113-131 (2018); J. Goldberg, "A senior White House official defines the Trump doctrine," Atlantic, June 11 (2018).

73. J. Sapir, "President Trump and free-trade," in Trumponomics: Causes and Consequences, Ed. by E. Fullbrook and J. Morgan (College Publications, 2017).

74. M. Ryner and A. Cafruny, The EU and Global Capitalism: Origins, Development, Crisis (Palgrave, MacMillan, London, 2017).

75. E. Husson, Paris-Berlin, La Survie de l'Europe (Gallimard, Paris, 2019).

76. C. H. Farnsworth, "A secret society of finance ministers,” New York Times, May 8 (1977). 